\title{
Oat Cover Crop and No-tillage Can Provide Weed Suppression and Alter Weed Community Dynamics in Sweet Corn
}

\author{
Emma K. Dawson ${ }^{1,2}$, George E. Boyhan ${ }^{1,2}$, Tim Coolong ${ }^{1,2}$, \\ Nicholas T. Basinger ${ }^{3}$, and Ryan McNeill ${ }^{1,2}$
}

ADDITIONAL INDEX WORDs. integrated weed management, multivariate statistics, organic weed control, sustainable agriculture, vegetable crops, Zea mays

Summary. Along with the many known benefits of cover crops, they may be an effective ecological weed management strategy in low-input agriculture. This research aimed to determine the effect of cover crops, combined with reduced-tillage and nitrogen inputs on sweet corn (Zea mays) yield and weed communities. During the 2-year study, the impact of the cover crop on yield varied. Yield within the notill conventional treatment plots was not significantly different from the conventional treatment [6844 and $7721 \mathrm{lb} /$ acre $(P=0.592)]$ in year 1 but differed in year $2(P=0.003)$. Weed density and experimental area covered by weeds were not significantly different between conventional and no-till conventional treatments. Multivariate analyses showed associations between specific weed species and management practices. Weeds were greatest in no-till organic treatments, and they had significantly lower yields, suggesting additional weed control beyond cover crops may be necessary for organic vegetable systems under reduced tillage.

W eeds competing for resources are the greatest threat to crop yield in vegetable systems (Bàrberi, 2002). Economic losses can be billions of dollars annually due to the cost of control, labor, and reduced yields (Soltani et al., 2016). Herbicides are the most common method of weed control used in agriculture. However, the recent increase in consumer interest in organic growing practices has led to a

Received for publication 20 Apr. 2021. Accepted for publication 8 Aug. 2021

Published online 21 October 2021.

${ }^{1}$ Department of Horticulture, Miller Plant Sciences Building, University of Georgia, 120 Carlton Street, Athens, GA 30602

${ }^{2}$ Durham Horticulture Farm, University of Georgia, 1221 Hog Mountain Rd, Watkinsville, GA 30677

${ }^{3}$ Crop and Soil Sciences Department, Miller Plant Sciences Building, University of Georgia, 120 Carlton Street, Athens, GA 30602

E.K.D. is a Graduate Student.

G.E.B. is the Principal Investigator, a Professor, and Extension Vegetable Specialist.

T.C. is a Professor.

N.T.B. is an Assistant Professor.

R.M. is a Farm Superintendent.

E.K.D. is the corresponding author. E-mail: ekd90262@uga.edu.

This is an open access article distributed under the CC BY-NC-ND license (https://creativecommons. org/licenses/by-nc-nd/4.0/).

https://doi.org/10.21273/HORTTECH04870-21 shift away from herbicides as the primary strategy for weed control. Many growers use hand weeding within high-value horticultural crops, but this requires extensive labor and is expensive (Fennimore and Doohan, 2008; Kruidhof et al., 2008). Organic agriculture relies on frequent tillage to control weeds. Intensive tillage damages soil structure (Mulvaney et al., 2011; Riley et al., 2008), leads to increased erosion, reduced infiltration rates (Busari et al., 2015; Karlen et al., 1994), and it releases carbon dioxide emissions from soil carbon stocks (Grandy et al., 2006), and can damage the crop. Controlling weeds in vegetable systems cannot be done using a single approach; success relies on integrated weed management (Kruidhof et al., 2008). Cover crops are a valuable component to be included in these integrated strategies.
Cover crops can suppress weeds through physical interference and $\mathrm{CO}^{-}$ mpetition for light (Teasdale and Mohler, 1993), buffered soil temperatures, increased habitat for weed seed predators (Haramoto and Gallandt, 2005), delayed release of plant-available nitrogen (Dyck and Liebman, 1995), and release of allelopathic chemicals (Creamer et al., 1996; Wortman et al., 2013). Higher cover crop biomass production is associated with increased weed suppression (Florence et al., 2019; Osipitan et al., 2018). Oat (Avena sativa) is a popular cover crop choice due to its fast growth habit and ability to produce substantial biomass (Clark, 2008; MacLaren et al., 2019). Under the proper conditions, biomass production is reportedly between 2004 and $4000 \mathrm{lb} / \mathrm{acre}$, in some cases was as high as $8026 \mathrm{lb} /$ acre (Clark, 2008). Cover crop species, management decisions, and termination timing are key to the successful adoption of cover crops as a weed control strategy.

Weed species, abundance, and pressure within agroecosystems can be modified based on different management practices; these practices may select certain species over others. Community assembly theory (Diamond, 1975) can be applied to weeds within agricultural systems. Different abiotic and biotic factors can act as ecological filters that alter a community trajectory (Booth and Swanton, 2002) over time. Practices that affect weed community assembly include herbicide use, crop rotation, and tillage practices (Barroso et al., 2015; Smith, 2006). Insight on how applied practices alter communities can explain weed population shifts related to reduced tillage or organic herbicides. Knowledge of weed community changes can influence the control needed. Research has shown that long-term reduced tillage systems tend to select for perennial weeds (Ngouajio et al., 2003; Thomas et al., 2004), whereas organic systems have higher

\begin{tabular}{llll}
\hline $\begin{array}{l}\text { Units } \\
\text { To convert U.S. to SI, } \\
\text { multiply by }\end{array}$ & U.S. unit & SI unit & $\begin{array}{l}\text { To convert SI to U.S., } \\
\text { multiply by }\end{array}$ \\
\hline 0.3048 & $\mathrm{ft}$ & $\mathrm{m}$ & 3.2808 \\
0.0929 & $\mathrm{ft}^{2}$ & $\mathrm{~m}^{2}$ & 10.7639 \\
2.54 & inch $(\mathrm{es})$ & $\mathrm{cm}$ & 0.3937 \\
25.4 & inch $(\mathrm{es})$ & $\mathrm{mm}$ & 0.0394 \\
0.4536 & $\mathrm{lb}$ & $\mathrm{kg}$ & 2.2046 \\
1.1209 & $\mathrm{lb} / \mathrm{acre}$ & $\mathrm{kg} \cdot \mathrm{ha}^{-1}$ & 0.8922 \\
$\left({ }^{\circ} \mathrm{F}-32\right) \div 1.8$ & ${ }^{\circ} \mathrm{F}$ & ${ }^{\circ} \mathrm{C}$ & $\left({ }^{\circ} \mathrm{C} \times 1.8\right)+32$
\end{tabular}


abundance and greater biodiversity of weeds compared with conventional systems (Pollnac et al., 2009).

Sweet corn (Zea mays) is well known for being a heavy feeding crop, with some reports recommending nitrogen rates between 200 and 300 lb/acre (Oktem et al., 2010; Sp, 2012). Cover crops such as oat are also known to tie up nitrogen, making it unavailable to the cash crop that follows. This study included additional nitrogen treatments to evaluate whether sweet corn grown following a cover crop requires additional fertilizer to obtain similar yields as conventionally grown sweet corn. This study was designed to determine the effect of the oat cover crop with reduced tillage and variable nitrogen on organic and conventional sweet corn. The main objectives were to assess the practicality of using cover crops within chemical and organic integrated weed management, determine if a reduced tillage system would result in a comparable sweet corn yield to a conventionally grown crop, and evaluate weed community characteristics among the different production practices.

\section{Materials and methods}

Site Description. The study was conducted in 2018-19 (year 1) and 2019-20 (year 2) at the University of Georgia Durham Horticulture Farm in Watkinsville, GA (lat. $33^{\circ} 53^{\prime} \mathrm{N}$, long. $\left.83^{\circ} 25^{\prime} \mathrm{W}\right)$. The experiment was arranged as a randomized complete block design with four replications. An oat cover crop was selected for its biomass potential. The cover crop seed was obtained from Athens Seed Co. (Watkinsville, GA). It was fall planted and spring killed before the study in years 1 and 2. Before cover crop termination in 2018 , biomass was sampled using a $0.6 \times 0.6-\mathrm{m}$ quadrat following the protocol described by Gaskin et al. (2015). The estimated fresh cover crop biomass was $4967 \mathrm{lb} /$ acre. The soil was a Cecil sandy loam (Fine, kaolinitic, thermicTypic Kanhapludults) with $\mathrm{pH}$ 6.1. Total precipitation during the experiment was $305 \mathrm{~mm}$ in year 1 and $228 \mathrm{~mm}$ in year 2 . The average daily temperature in year 1 was 22.2 and $25.8^{\circ} \mathrm{C}$ in year 2 (Fig. 1).

Two methods were used to prepare fields before planting, conventional tillage and no-till. In the no-till treatments, cover crop residue was left on the surface. Treatments included conventional tillage (Conv), no-till using conventional herbicides (NT Conv), and no-till using organic herbicides (NT Org). An increased nitrogen treatment was included to overcome the initial nutrient tie-up caused by the cover crop (Clark, 2008; Doran and Smith, 1991; Hartwig and Ammon, 2002). These treatments consisted of an organic no-till $(\mathrm{NT}$ Org $+\mathrm{N})$ and a conventional no-till (NT Conv $+\mathrm{N}$ ), both with $50 \%$ more nitrogen (Table 1). The check plot served as the control in each replication. It was prepared following conventional practices but received no herbicides or weed management. The cover crop in all treatments was ended chemically and mechanically. Conventional plots were chisel plowed and tilled as usual. Before planting, conventional plots were treated with preemergent herbicides typical of a traditional field corn weed management plan. Organic treatments followed National Organic Program guidelines (U.S. Department of Agriculture, 2017). All fertilizer was applied by hand to reduce potential contamination between treatments. Herbicides were applied in the mornings under calm conditions to avoid any carryover between plots. 'Obsession' sweet corn, a bicolor supersweet (sh2) variety, was purchased from Seedway (Hall, NY).

Year 1. Oat cover crop was direct seeded on 20 Sept. 2018 at a rate of $60 \mathrm{lb} /$ acre. The cover crop was ended 2 weeks before the planting date on 18 Mar. 2019. The termination method for the conventional treatments included a burndown herbicide application of $0.71 \mathrm{lb} / \mathrm{acre}$ glyphosate (Mad Dog; Loveland Products, Loveland, CO) based on recommendations (Hill and Sprague, 2021; Legleiter et al., 2012). After chemical termination, the cover crop was flail mowed using a flail mower (Vrisimo MiniMax 72 inches; Valley Tool Manufacturing Co., Hughson, CA). Conventional plots were subsequently tilled (Kuhn Power Tiller 72 inches; Kuhn North America, Columbia, TN) to prepare for planting. In the no-till plots following chemical and mechanical termination, the residue was left on the soil surface. Cover crop in the organic plots was ended using glacial acetic acid $\left(\mathrm{CH}_{3} \mathrm{COOH}\right)$ diluted to $20 \%$ (Duda Energy, Decatur, AL). Before planting, conventional plots received a preemergent herbicide application of atrazine at $1.4 \mathrm{lb} /$ acre. (Southern $\mathrm{Ag}$, Rubonia, FL) and S-metolachlor at $0.98 \mathrm{lb} /$ acre (Dual II Magnum; Syngenta, Greensboro, NC) following recommendations for sweet corn production in the region (Culpepper, 2015). No other plots received additional preemergent weed control. Each treatment plot had a total area of 350 $\mathrm{ft}^{2}(25 \times 14 \mathrm{ft})$ with a 10 - $\mathrm{ft}$ buffer between plots. Two sprinklers (Orbit Irrigation Products, Bountiful, UT) were placed within each replication. Irrigation was applied with the aim of 1 to 1.5 inches per week throughout the experiment's duration, depending on rainfall.

'Obsession' sweet corn was directseeded on 11 Apr. 2019 using a vacuum planter (1991 model 7300 MaxEmerge; John Deere, Moline, IL) with a no-till coulter (Dawn Equipment Co., Sycamore, IL) followed by a seed firmer (Keeton; Precision Planting, Tremont, IL) and spiked closing wheels (Dawn Equipment Co.). Sweet corn was seeded at 11 -inch in-row spacing on 36 inches center to center. In 2019, sweet corn was planted in two passes creating eight total rows within each plot.

The two fertilizer rates were 200 and $300 \mathrm{lb} /$ acre. Half of the fertilizer was surface applied by hand at planting 100 and $150 \mathrm{lb} / \mathrm{acre}$, for the low and high rates, respectively. For the conventional treatments, $10 \mathrm{~N}-4.4 \mathrm{P}-8.3 \mathrm{~K}$ fertilizer was used. The organic plots received $5 \mathrm{~N}-1.8 \mathrm{P}-2.5 \mathrm{~K}$ (Harmony $\mathrm{Ag}$ Organic Fertilizer, Check, VA). The remaining nitrogen was side-dressed by hand 6 weeks after planting, 22 May 2019. The nitrogen source was dependent on the treatments; conventional plots received calcium nitrate (15N-0P-0K; Yara North America, Tampa, FL), whereas feather meal (13N-0P-0K; Mason City By-Products, Mason City, IA) was applied to the organic plots. Corn was harvested at maturity indicated by brown silks on 21 June 2019. Ears were harvested from the four inner rows to avoid edge effects. Measurements of crop yield were taken at harvest, and weed data were collected twice during the season.

YeAR 2. The experimental methods were repeated for the second year with a few changes. Due to the land available at the Durham Horticulture Farm, the exact experiment location 
A)

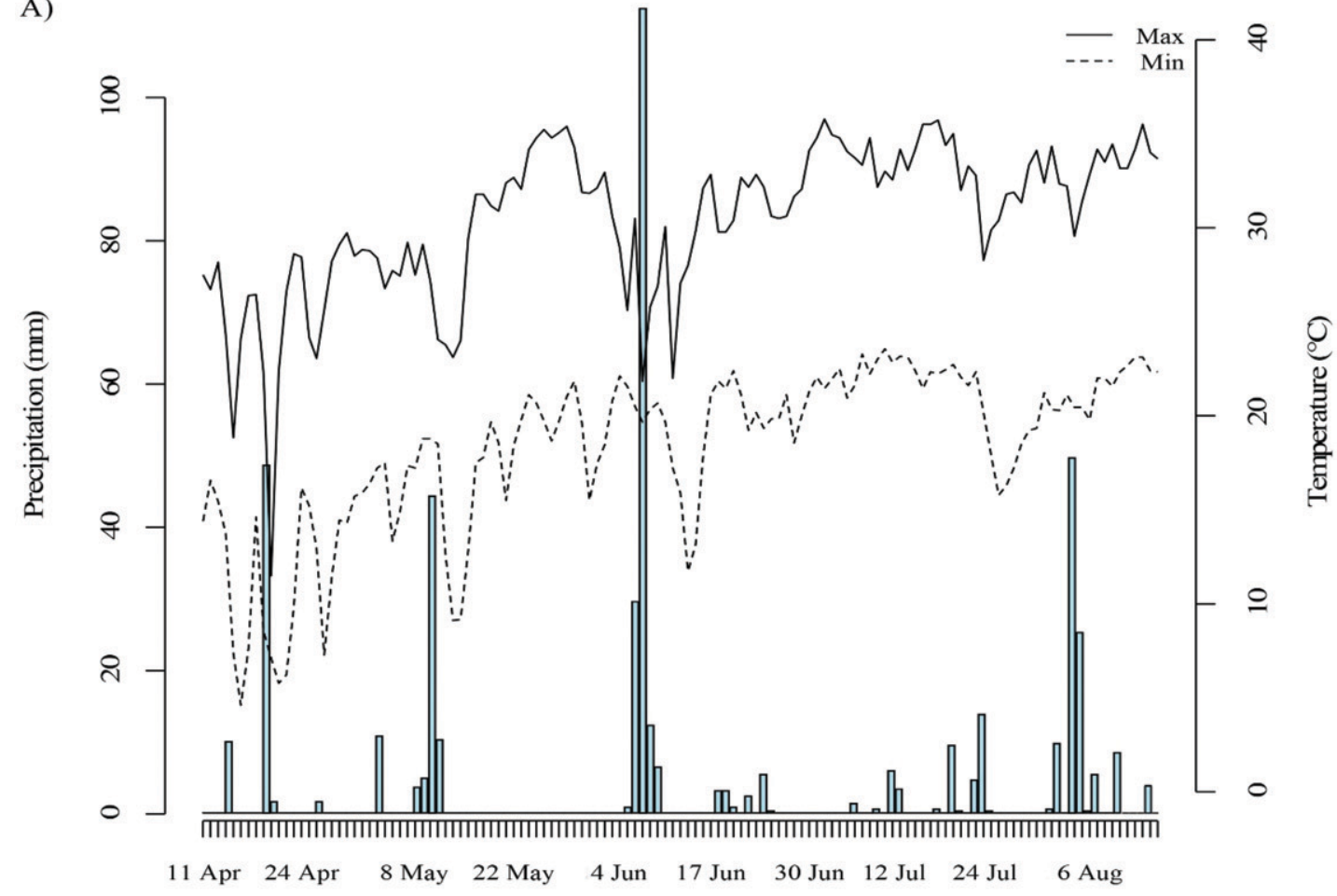

B)

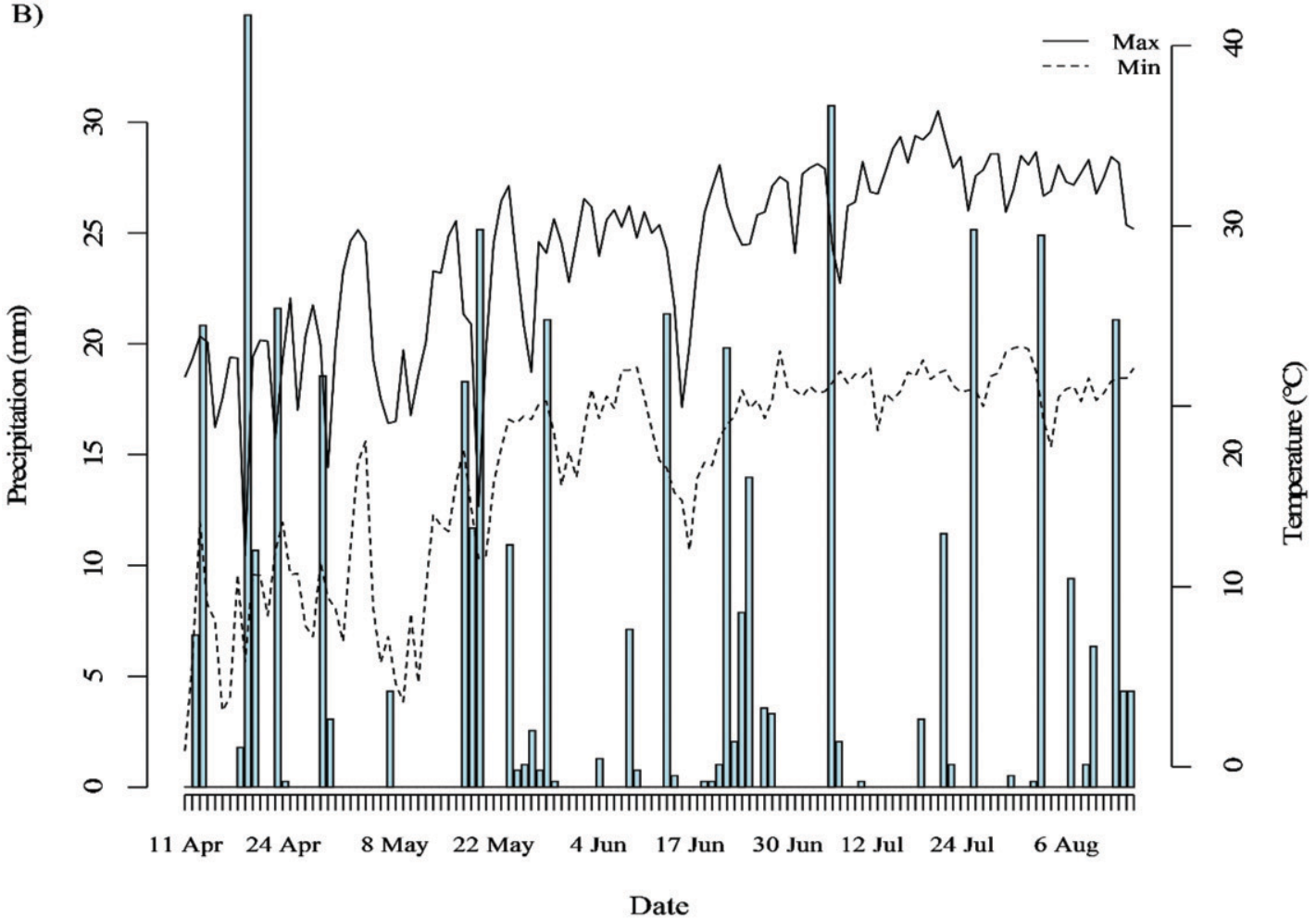

Fig. 1. Maximum and minimum air temperatures and rainfall events during the 'Obsession' sweet corn growing season from (A) year 1 (2018-19) and (B) year 2 (2019-20). Data collected from the Watkinsville-Horticulture weather station in Oconee County, GA (University of Georgia, 2020); $1.8 \times{ }^{\circ} \mathrm{C}+32={ }^{\circ} \mathrm{F}, 1 \mathrm{~mm}=0.0394$ inch.

differed from year 1 . Plots had a total area of $360 \mathrm{ft}^{2}(6 \times 60 \mathrm{ft})$ with a $10-\mathrm{ft}$ buffer between them. The crop was planted in one pass instead of two like the previous year, resulting in plots with four rows of sweet corn. The experiment was delayed due to COVID-19 restrictions.

The oat cover crop was planted in 27 Sept. 2019 and ended on 27 May 2020, 2 weeks before planting the sweet corn crop. Termination methods followed those from year 1. Before planting, conventional treatments received a preemergent herbicide application of $1.4 \mathrm{lb} /$ acre atrazine and $0.98 \mathrm{lb} /$ acre $\mathrm{S}$-metolachlor. Half of the fertilizer was applied as a preplant on 1 June 2020. 
Table 1. Description of the six treatments applied to 'Obsession' sweet corn from experimental year 1 (2018-19) and year 2 (2019-20) at Watkinsville, GA, with abbreviations.

\begin{tabular}{|c|c|c|}
\hline Treatment & Abbreviation & Description of treatment ${ }^{\mathrm{z}}$ \\
\hline Check & - & $\begin{array}{l}\text { Plots were plowed and tilled but received } \\
\text { no herbicide treatments or other form of } \\
\text { weed control. Fertilizer applied as rate of } \\
200 \mathrm{lb} / \text { acre, the same as the } \\
\text { conventional, no-till conventional, and } \\
\text { no-till organic treatments. }\end{array}$ \\
\hline No-till conventional & NT Conv & $\begin{array}{l}\text { Cover crop ended with glyphosate. Residue } \\
\text { was mowed and left on the soil surface. } \\
\text { Plots were not tilled. Received } \\
\text { conventional fertilizer at the regular rate } \\
(200 \mathrm{lb} / \text { acre }) \text {. }\end{array}$ \\
\hline Conventional & Conv & $\begin{array}{l}\text { Plots were plowed and tilled. Prepared } \\
\text { following typical field corn production } \\
\text { practices, including preemergent herbicide } \\
\text { application. Received conventional } \\
\text { fertilizer at rate of } 200 \mathrm{lb} / \text { acre. }\end{array}$ \\
\hline No-till organic & NT Org & $\begin{array}{l}\text { Cover crop treated with acetic acid } \\
\text { followed by mowing for termination. } \\
\text { Residue left on the soil surface. Plots } \\
\text { received organic sources of fertilizer at } \\
\text { the regular rate of } 200 \mathrm{lb} / \text { acre. }\end{array}$ \\
\hline $\begin{array}{l}\text { No-till conventional } \\
\quad+\mathrm{N}\end{array}$ & $\mathrm{NT}$ Conv $+\mathrm{N}$ & $\begin{array}{l}\text { Cover crop ended with glyphosate. Residue } \\
\text { was mowed and left on the soil surface. } \\
\text { Plots were not tilled. Received } 50 \% \text { more } \\
\text { conventional fertilizer, } 300 \mathrm{lb} / \text { acre. }\end{array}$ \\
\hline No-till organic $+\mathrm{N}$ & $\mathrm{NT}$ Org $+\mathrm{N}$ & $\begin{array}{l}\text { Cover crop treated with acetic acid followed } \\
\text { by mowing for termination. Residue left } \\
\text { on the soil surface. Plots received organic } \\
\text { sources of fertilizer at } 50 \% \text { more than the } \\
\text { regular rate, } 300 \mathrm{lb} / \text { acre. }\end{array}$ \\
\hline
\end{tabular}

The crop was direct seeded on 2 June 2020 using the no-till vacuum seeder. The remaining nitrogen was side dressed by hand 6 weeks after planting on 14 July 2020. Overhead irrigation was applied at the rate of 1 to 1.5 inches, dependent on rainfall. Sweet corn was harvested at maturity on 12 Aug. 2020, 10 weeks after planting. Crop yield measurements were taken at harvest.

COMPONENTS OF CROP YIELD. Yield and yield components were evaluated to determine the impact of the treatments on crop yield. The total weight and number of all harvested ears from each plot were documented, the yield was then extrapolated to pounds per acre. The length, width, and tip fill of five randomly sampled ears from each plot were recorded. Tip or kernel fill is used as a measurement of quality. Poor tip fill is caused by various issues, including insects, environmental stress, or poor pollination (Nielsen, 2003). Tip fill was recorded on a scale of 1 to 5 , with 1 being poor and 5 being excellent. Tip fill was rated by one person in both years to avoid bias. Within each treatment plot, the heights of five representative plants were measured at harvest.

Population complex. Weeds were sampled using a $0.3 \times 0.3-\mathrm{m}$ $\left(0.09 \mathrm{~m}^{2}\right)$ quadrat randomly tossed inside each plot six times following an " $\mathrm{X}$ " pattern to ensure a representative sample. The number of weeds and species within the quadrat was recorded. Weed density per square meter was calculated from the total weeds per plot, based on the formula modified from Booth et al. (2010; Nkoa et al., 2015). In both years, weed counts were taken at 5 and 9 weeks after planting to see the weed population shifts throughout the growing season. Percent coverage of the plots was determined by visual estimation of the percentage of ground covered by weeds within each plot.

Statistical analysis. This study was designed to evaluate the effect of cover crop and no-till production practices on yield and weed populations. Statistical analyses were done using $\mathrm{R}$ statistical software ( $\mathrm{R}$ version 3.6.3; $\mathrm{R}$ Foundation for Statistical Computing, Vienna, Austria). Analysis of variance (ANOVA) was used to analyze yield data. Preplanned comparisons were chosen a priori to focus on comparisons of scientific interest between specific treatments. We were interested in comparing the conventional plots with the no-till conventional plots, as one of the disadvantages of no-till agriculture can be yield reduction. Other contrasts included comparing treatments with added nitrogen to those without and conventional compared with organic treatment. Significance was set at the $\alpha$ $\leq 0.05$ level. The yield was significantly different between experimental years. Magnitude differences can result in treatment $\times$ year interactions, so data from years 1 and 2 were analyzed separately.

The weed data from year 1 was recorded as presence-absence data of species within the sampling quadrat and the total number of weeds. Data from year 2 included total overall weed count and totals by individual species. The number of weeds per sample was counted and summed for each treatment plot. Count data were log-transformed to fit normality assumptions. Weeds within each plot were compared using ANOVA. Significance $(\alpha \leq$ 0.05) was determined with Tukey's honestly significant difference (HSD) for all treatment effects. Percent coverage scores were transformed for normality using the angular transformation (Freeman and Tukey, 1950). Transformed data were analyzed using ANOVA followed by Tukey's HSD at $\alpha \leq 0.05$ level. Weed count data from year 2 was further analyzed using multiple multivariate statistical analyses, including nonmetric multidimensional scaling (NMDS), Kruskal-Wallis ANOVA, multiple response permutation procedure [MRPP (Zimmerman et al., 1985)], and an indicator species analysis (ISA). Previous research has indicated that management practices lead to weed population shifts, modifying species abundance and pressure over time (Barroso et al., 2015; Buhler et al., 1994; Tuesca et al., 2001). These statistical analyses were used to identify the differences in species abundance and distribution based on treatment. 
To visualize the relationship between data points in multidimensional space, NMDS was employed (McCune et al., 2002). The output provides a map of $n$ individuals in the ordination space. Proposed guidelines for interpretation of NMDS recommend that stress is between $<0.05$ and 0.1 to make accurate conclusions. Higher stress values may be usable but can potentially provide misleading results (Clarke, 1993). Before the analysis, 2019-20 weed data were separated by sampling date and transformed using a $(\log 10 \mathrm{x}+1)$ transformation. The number of random restarts supplied to the function was 100 , with three dimensions $(k)$, using Gower's distance (Gower, 1971).

A Kruskal-Wallis ANOVA was used to determine statistically significant differences between weed species within the different treatment plots, followed by Dunn's test, a nonparametric post hoc test comparing treatment groups. MRPP also provides a test of significance between groups of sampling units using a dissimilarity matrix. MRPP provides information on differences between the treatments. It does not indicate which species are causing the differences. The MRPP was followed by post hoc pairwise comparisons and ISA (Dufrêne and Legendre, 1997). ISA uses the species abundance and frequency to produce a maximum indicator value for each species to determine indicators of site groups. In this analysis, the groups were the treatments. The indicator index value (IV) measures the association between a species and the site group and then looks for the group corresponding to the highest association value. A permutation test determines the statistical significance of this relationship at the $P<$ 0.05 level. The NMDS and MRPP were both performed using the "vegan" package (Oksanen et al., 2020). R package, "indicspecies," was used to complete the ISA (Cáceres and Legendre, 2009).

\section{Results and discussion}

WeEd PREssure. Data were separated by year and sampling date for the analysis. Weed species present within treatment plots differed between the years. Approximately 30 weed species were identified in year 1 . Of the species present, eighteen were annual broadleaves; eight were perennial broadleaves, three were annual grasses, and

Table 2. Percent area covered with weeds and weed density within 'Obsession' sweet corn plots at Watkinsville, GA, at 5 and 9 weeks after planting in year 2 (2019-20). See Table 1 for detailed treatment descriptions.

\begin{tabular}{|c|c|c|c|c|}
\hline \multirow[b]{2}{*}{ Treatment } & \multicolumn{2}{|c|}{ Coverage (\%) } & \multicolumn{2}{|c|}{ Mean density (weeds $\left./ \mathrm{m}^{2}\right)^{\mathrm{z}}$} \\
\hline & $5 \mathrm{wk}$ & 9 wk & 5 wk & 9 wk \\
\hline & \multicolumn{4}{|c|}{2019} \\
\hline Check & $0.75 b^{y}$ & $0.81 \mathrm{~b}$ & $0.89 \mathrm{~b}$ & $0.86 \mathrm{~b}$ \\
\hline NT Conv & $0.18 \mathrm{a}$ & $0.14 \mathrm{a}$ & $0.20 \mathrm{a}$ & $0.22 \mathrm{a}$ \\
\hline Conventional & $0.15 \mathrm{a}$ & $0.19 \mathrm{a}$ & $0.16 \mathrm{a}$ & $0.28 \mathrm{a}$ \\
\hline NT Org & $0.83 \mathrm{c}$ & $0.91 \mathrm{~b}$ & $0.96 \mathrm{~b}$ & $0.85 \mathrm{~b}$ \\
\hline NT Org + N & $0.80 \mathrm{c}$ & $0.88 \mathrm{~b}$ & $0.85 \mathrm{~b}$ & $1.06 \mathrm{~b}$ \\
\hline $\mathrm{NT}$ Conv $+\mathrm{N}$ & $0.23 \mathrm{ab}$ & $0.16 \mathrm{a}$ & $0.26 \mathrm{a}$ & $0.27 \mathrm{a}$ \\
\hline \multirow[t]{2}{*}{ Significance } & 0.0005 & $<0.0001$ & $<0.0001$ & 0.0002 \\
\hline & \multicolumn{4}{|c|}{2020} \\
\hline Check & $0.74 \mathrm{~b}$ & $1.0 \mathrm{~b}$ & $1.02 \mathrm{c}$ & $1.15 \mathrm{~b}$ \\
\hline NT Conv & $0.01 \mathrm{a}$ & $0.1 \mathrm{a}$ & $0.19 \mathrm{ab}$ & $0.28 \mathrm{a}$ \\
\hline Conventional & $0.0 \mathrm{a}$ & $0.02 \mathrm{c}$ & $0.05 \mathrm{a}$ & $0.06 \mathrm{c}$ \\
\hline NT Org & $0.68 \mathrm{~b}$ & $0.99 \mathrm{~b}$ & $0.67 \mathrm{bc}$ & $0.91 \mathrm{~b}$ \\
\hline NT Org + N & $0.56 \mathrm{~b}$ & $0.99 \mathrm{~b}$ & $0.47 \mathrm{bc}$ & $0.94 \mathrm{~b}$ \\
\hline $\mathrm{NT}$ Conv $+\mathrm{N}$ & $0.02 \mathrm{a}$ & $0.16 \mathrm{a}$ & $0.18 \mathrm{a}$ & $0.28 \mathrm{a}$ \\
\hline Significance & $<0.0001$ & $<0.0001$ & $<0.0001$ & $<0.0001$ \\
\hline
\end{tabular}

one was perennial grass. In year 2,18 species were identified during the study: eight annual broadleaves, three perennial broadleaves, five annual grass species, and one perennial grass (Supplemental Table 1).

Differences were discovered among weed density and percent coverage between the treatments in year 1 and year 2 (Table 2 ). In year 1 , at 5 weeks after planting the check, NT Org and NT Org + N had the highest weed density, between 0.85 to 0.96 weeds $/ \mathrm{m}^{2}$. These three treatments were not significantly different from each other but differed from the Conv, NT Conv, and NT Conv $+\mathrm{N}$ plots. The latter three treatments had significantly fewer weeds. At 9 weeks, the NT Conv and NT Conv $+\mathrm{N}$ treatments had mean densities of 0.22 and 0.27 weeds $/ \mathrm{m}^{2}$, both less than the Conv treatment's mean density. At 5 weeks after planting, both the NT Org and NT Org + N treatments had the highest weed pressure, which was not significantly different from the check. The NT Conv, NT Conv $+\mathrm{N}$, and Conv treatments had significantly fewer weeds than the organic treatments. These trends persisted 9 weeks after planting. By 9 weeks, the percent of the NT Org and NT Org + N plots covered by weeds was between $88 \%$ and $91 \%$. Neither treatment differed significantly from the check. The area covered by weeds in the NT Conv, $\mathrm{NT}$ Conv $+\mathrm{N}$, and Conv was between 14 and 19\%, with the no-till plots having a slightly lower percent coverage. Percent coverage and mean density were the lowest in the NT Conv and NT Conv $+\mathrm{N}$ treatment plots.

In year 2, the NT Org and NT Org $+\mathrm{N}$ treatments again had the highest weed density, besides the check, but density was slightly less than in year 1 , with 0.67 and 0.47 weeds $/ \mathrm{m}^{2}$, respectively (Table 2 ). At 5 weeks after planting, the NT Org and NT Org + N treatments were not significantly different from the NT Conv treatment. The weed density increased to 0.91 weeds $/ \mathrm{m}^{2}$ and 0.94 weeds $/ \mathrm{m}^{2}$ by week 9 . Weed density in the NT Conv plots was significantly lower than the NT Org plots but greater than the Conv treatment. The NT Org and NT Org $+\mathrm{N}$ treatments seemed to provide better weed control initially in year 2 . At the first sampling date, 5 weeks after planting, the percent of the treatment plot covered by weeds was between $56 \%$ and $68 \%$. Although weeds covered less area than in 2019, they still had significantly more weed pressure than the NT Conv, NT Conv $+\mathrm{N}$, and Conv treatments. By the 9-week sampling date, the plot area covered was almost 


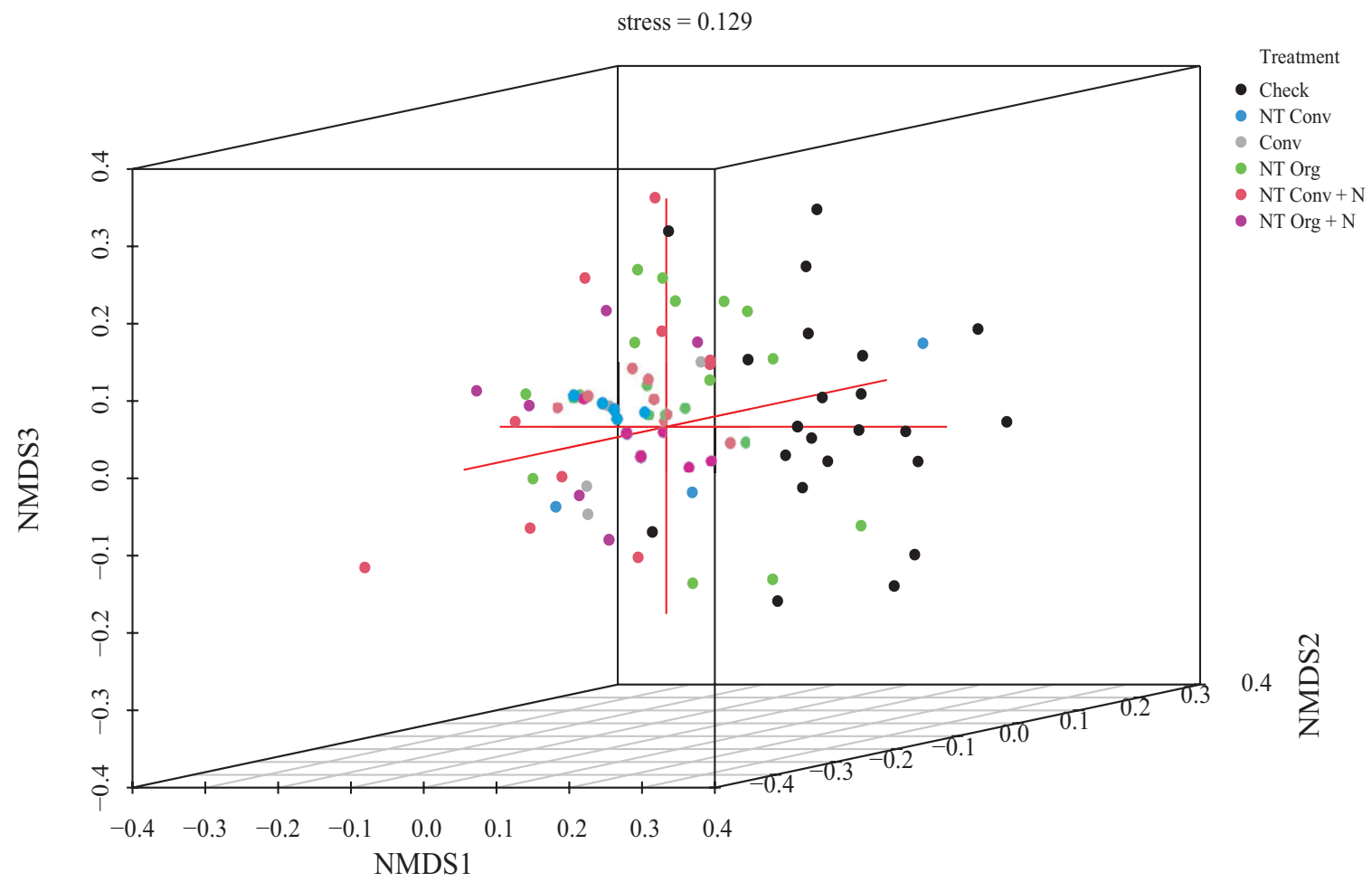

Fig. 2. Plots of three-dimensional nonmetric multidimensional scaling (NMDS) solution of weed flora at 5 weeks after 'Obsession' sweet corn planting in year 2 at Watkinsville, GA. The distribution of weeds within the treatments are significantly different, based on the analysis of similarity $(R=0.163, P=0.004)$. See Table 1 for treatment descriptions.

$100 \%$. The NT Conv, NT Conv $+\mathrm{N}$, and Conv treatments had very low weed pressure at 5 weeks, $1 \%, 0 \%$, and $2 \%$, respectively. At 9 weeks, the area covered increased to $10 \%, 2 \%$, and $16 \%$. The NT Conv and NT Conv $+\mathrm{N}$ were not significantly different from one another at 9 weeks; however, the Conv treatment was significantly different from all the treatments based on Tukey's HSD.

None of the plots received any additional weed control throughout the season in either year, so these results are promising. The cover crop in the NT Conv and NT Conv $+\mathrm{N}$ treatment performed season-long weed suppression as well as the conventional preemergent herbicides and tillage used in the Conv treatment. On the basis of the results from both years of the experiment, using cover crops with no additional weed control practices may not be applicable in an organic system. However, using cover crops and reduced tillage as part of an integrated weed management plan could lower herbicide use by reducing the amount of postemergent herbicide applications throughout the season while providing weed suppression along with the additional benefits offered by reduced tillage.
Weed communities. The null hypothesis of the NMDS ordination is that the weed community data are unstructured, and there are no differences between the treatment groups. The NMDS provides a stress value that is a product of a normalized loss function. A stable solution was reached after 25 and 50 runs for the two sampling dates. The stress values for weeks 5 and 9 were 0.129 and 0.101 , respectively. At 5 weeks after planting, the distribution of weeds within the check and both NT Org treatments are clustered together on the right side of the graph (Fig. 2). Weeds in the Conv and NT Conv treatments are crowded together at the top left, with the other treatments being dispersed through the ordination space. Shepard's graph (Fig. 3) indicates a strong relationship between the NMDS ordination distance and the originally observed distance (nonmetric $R^{2}=0.98$, linear $\left.R^{2}=0.94\right)$ at 5 weeks. Later at 9 weeks after planting, the distribution of weeds within the treatment groups becomes more defined in the ordination space (Fig. 4). The Check and NT Org are again primarily distributed through the bottom right quadrant.
NT Conv and NT Org $+\mathrm{N}$ are distributed on the left side in the upper and lower quadrants of the graph. The Conv is near the center and has the fewest points. The NT Conv + $\mathrm{N}$ treatment is in the upper right quadrant and is more isolated from the other groups. The shepherd's plot at 9 weeks (Fig. 5) again shows a strong relationship between the NMDS ordination distance and the originally observed distance (nonmetric $R^{2}=$ 0.99 , linear $\left.R^{2}=0.95\right)$. The NMDS plots show that the patterns of weed distribution differ within the treatments. These analyses were performed after one season under no-till. In a long-term reduced tillage system, more defined patterns would be expected to emerge. The subsequent analyses confirm the initial findings by the NDMS that the treatments influenced species frequency and distribution.

At 5 weeks, the Kruskal-Wallis ANOVA found carpetweed (Mollugo verticillata), crabgrass (Digitaria sanguinalis), buckwheat (Polygonum convolvulus), and goosegrass (Eleusine indica) were different between the treatments. By the 9-week sampling, 


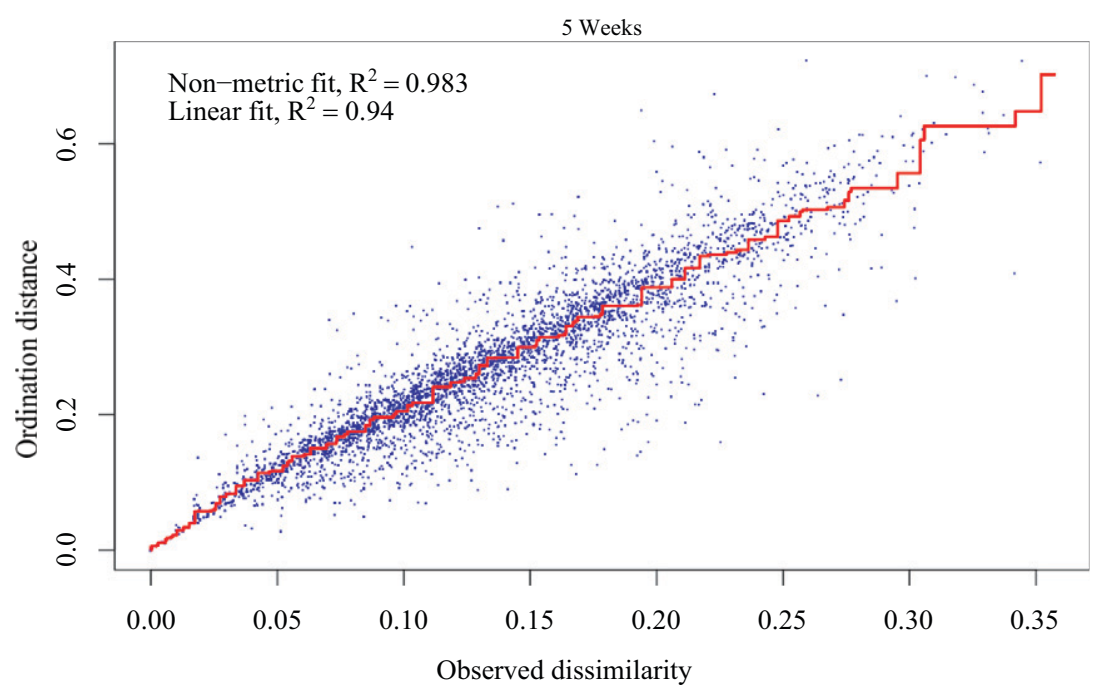

Fig. 3. Shepard's plot for the week 5 nonmetric multidimensional scaling (NMDS) results. $R^{2}$ values indicate a strong relationship between the NMDS ordination distance of weed species and the original observed distance of weeds present in the treatment plots at 5 weeks after 'Obsession' sweet corn planting in year 2 (2019-20) at Watkinsville, GA.

carpetweed, crabgrass, and goosegrass were still different among treatments (Table 3 ), along with two additional species, pigweed (Amaranthus sp.) and oat. Oat was used as the cover crop in the experiment but was classified as a weed if plants persisted after termination. Dunn's test revealed in which treatments species differed (Table 4).Carpetweed was significantly different between the check and all other treatments at both sampling dates. Carpetweed was significantly different in the check compared with all other treatments at both sampling dates. Crabgrass, buckwheat, and goosegrass were significantly different in the check at 5 weeks. At 9 weeks, oat and crabgrass were significantly different in the check. Crabgrass abundance was different in the NT Conv, Conv, and NT Org compared with NT Org $+\mathrm{N}$ and NT Conv $+\mathrm{N}$. Goosegrass was significantly different in the check from all other treatments except NT Conv $+\mathrm{N}$. After the initial analysis, further tests were done using MRPP and ISA to examine the weed community makeup further.

The results from the MRPP (Table 5) confirmed the previous analyses that there were significant differences in the weed populations of the treatment groups at both 5 and 9 weeks $(P=0.001)$. The A-value is the chance corrected within-group agreement $[\mathrm{A}=1-$ (observed $\delta /$ expected $\delta$ )] at both sampling dates A was greater than 0 . This indicates that the weed populations within the treatment groups were more similar than communities between treatment groups. The pairwise comparisons following the MRPP (Table 6) identified treatments with significantly different

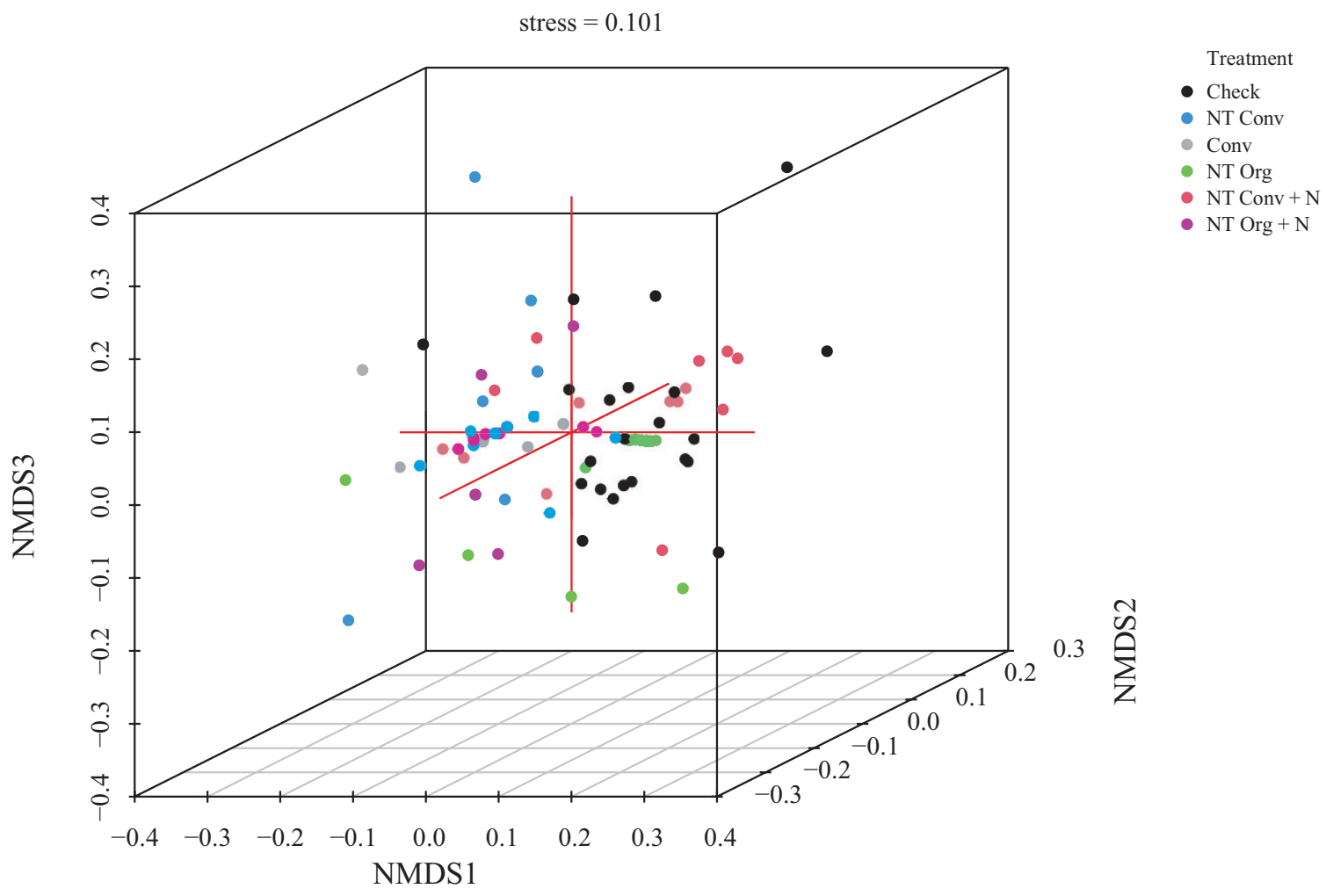

Fig. 4. Plots of three-dimensional nonmetric multidimensional scaling (NMDS) solution of weed flora at 9 weeks after 'Obsession' sweet corn planting in year 2 at Watkinsville, GA. The distribution of weeds within the treatments are significantly different, based on the analysis of similarity $(R=0.269, P=0.004)$. See Table 1 for treatment descriptions. 


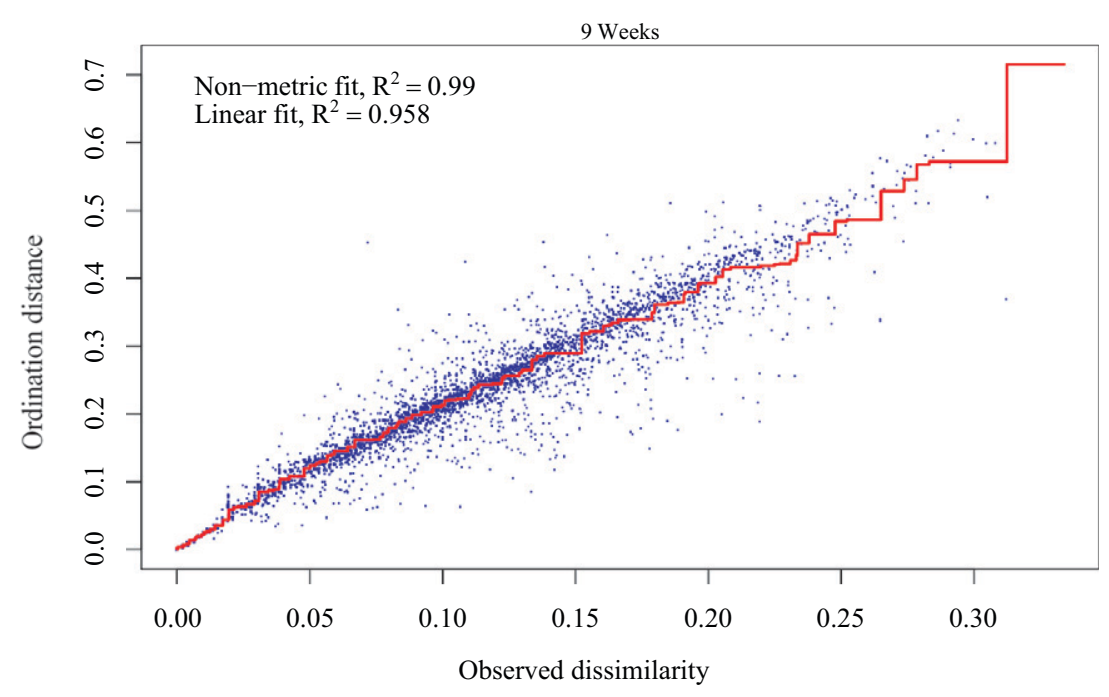

Fig. 5. Shepard's plot for week 9 nonmetric multidimensional scaling (NMDS) results. $R^{2}$ values indicate a strong relationship between NMDS ordination distance of weed species and the original observed distance of weeds present in the treatment plots 9 weeks after 'Obsession' sweet corn planting in year 2 (2019-20). weed populations. The abundance of weeds in the Check treatments differed significantly from all other treatments at both dates $(P=0.003)$. Weed species and abundance in the Conv and NT Conv plots were only different from the NT Org at 5 weeks and both NT Org and NT Org + N at 9 weeks.
These results correspond to the initial ANOVA performed on the weed density and coverage data. The NT Conv and NT Conv $+\mathrm{N}$ were not significantly different from the Conv plots $(P$ $=0.002)$ at 9 weeks after planting. This provides further evidence that cover crops when used in combination with
Table 3. Differences in weed species present between treatments at 5 and 9 weeks after 'Obsession' sweet corn planting in year 2 (2019-20) at Watkinsville, GA, as determined by Kruskal-Wallis analysis. See Supplemental Table 1 for more detailed information on weed species.

\begin{tabular}{|c|c|c|c|c|c|}
\hline \multirow[b]{3}{*}{ Common name } & \multirow[b]{3}{*}{ Scientific name } & \multicolumn{4}{|c|}{ Sampling period } \\
\hline & & \multicolumn{2}{|c|}{5 weeks } & \multicolumn{2}{|c|}{9 weeks } \\
\hline & & $\chi^{2}$ & $P$ value $^{\mathrm{z}}$ & $\chi^{2}$ & $P$ value ${ }^{\mathrm{z}}$ \\
\hline Oat & Avena sativa & 5.19 & 0.39 & 16.8 & 0.005 \\
\hline Carpetweed & Mollugo verticillata & 79.2 & $<0.001$ & 22.9 & 0.003 \\
\hline Crabgrass & Digitaria sanguinalis & 51.9 & $<0.001$ & 93.5 & $<0.001$ \\
\hline Pigweed & Amaranthus sp. & 10.9 & 0.05 & 13.9 & 0.02 \\
\hline $\begin{array}{l}\text { Cut leaf evening } \\
\text { primrose }\end{array}$ & Oenothera laciniata & 8.25 & 0.14 & 3.04 & 0.69 \\
\hline Nudsedge & Cyperus sp. & 3.46 & 0.63 & 6.96 & 0.22 \\
\hline Morningglory & Ipomoea purperea & 5.65 & 0.34 & 8.93 & 0.11 \\
\hline Buckwheat & Polygonum convolvulus & 15.5 & 0.008 & 5.0 & 0.42 \\
\hline Buckhorn plantain & Plantago lanceolata & 4.07 & 0.54 & - & - \\
\hline Eclipta & Eclipta prostrata & 4.07 & 0.54 & 4.03 & 0.55 \\
\hline Goosegrass & Eleusine indica & 17.5 & 0.004 & 33.7 & $<0.001$ \\
\hline Oxalis & Oxalis stricta & 11.3 & 0.05 & 5 & 0.42 \\
\hline Watermelon & Citrullus lanatus & 4.24 & 0.52 & 5 & 0.42 \\
\hline Deertongue & Panicum clandestinum & 5.04 & 0.41 & - & - \\
\hline Spotted spurge & Euphorbia maculata & - & - & 4.03 & 0.55 \\
\hline Flatsedge & Cyperus odoratus & - & - & 5 & 0.42 \\
\hline Annual bluegrass & Poa annua & 5.04 & 0.41 & - & - \\
\hline Cudweed & Gnaphalium spicatum & - & - & 4.03 & 0.55 \\
\hline
\end{tabular}

${ }^{\mathrm{z}}$ Significance of treatment effects at the 0.05 level. reduced tillage, they can provide similar weed control to conventionally managed systems. However, when used in organically managed systems, cover crops did not suppress weeds as effectively.

The ISA identified four significant species at week 5 , carpetweed, crabgrass, buckwheat, and goosegrass (Table 7). These results are consistent with the Kruskal Wallis ANOVA results, which found the same species significant. Carpetweed was strongly (IV $=0.838, P=0.001)$ associated with the check. Buckwheat was significantly associated with the check but was not as strong of an indicator. The two components reported by the ISA provide further information about species composition. Component A is the probability that a sampled site belongs to the target site group, given that the species was found. Component $B$ is the sample estimate of the probability of finding the species in sites belonging to the site group (Dufrêne and Legendre, 1997). For carpetweed, $\mathrm{A}=0.8017$, meaning it occurs in most sites belonging to the check, but $\mathrm{B}=0.875$, so the species was not present at every plot within this treatment. The species related to the no-till treatments are of greater interest within the scope of this study.

Goosegrass was associated with the check, and NT Org (IV $=0.373$, $P=0.013$ ) and crabgrass were strongly associated with the check, NT Org, and NT Org + N (IV = 0.75l, $P=0.001)$. The same four species were significant at 9 weeks after planting, along with pigweed and oat. Goosegrass and pigweed were associated with the check and NT Org $+\mathrm{N}$ treatments. Crabgrass was strongly and significantly associated with the check, NT Org, and NT Org + N treatments $(\mathrm{IV}=0.933, P=0.001)$. Oat was the only species related to the NT Conv and NT Conv $+\mathrm{N}$ treatments (IV $=$ $0.486, P=0.012$ ). This is likely due to incomplete termination of the cover crop in the NT Conv plots before planting. Of these significant species, three are annual broadleaves, and two are annual grasses, with one perennial grass. The annual broadleaf species were only related to the check and the two NT Org treatments.

In contrast, the only species strongly associated with the NT Conv treatments was an annual grass species. 
Table 4. Post hoc comparisons for the effect of treatments on weed species present between 'Obsession' sweet corn experimental plots at Watkinsville, GA, in year 2 (2019-20). See Table 1 treatment descriptions and Supplemental Table 1 for further weed species information.

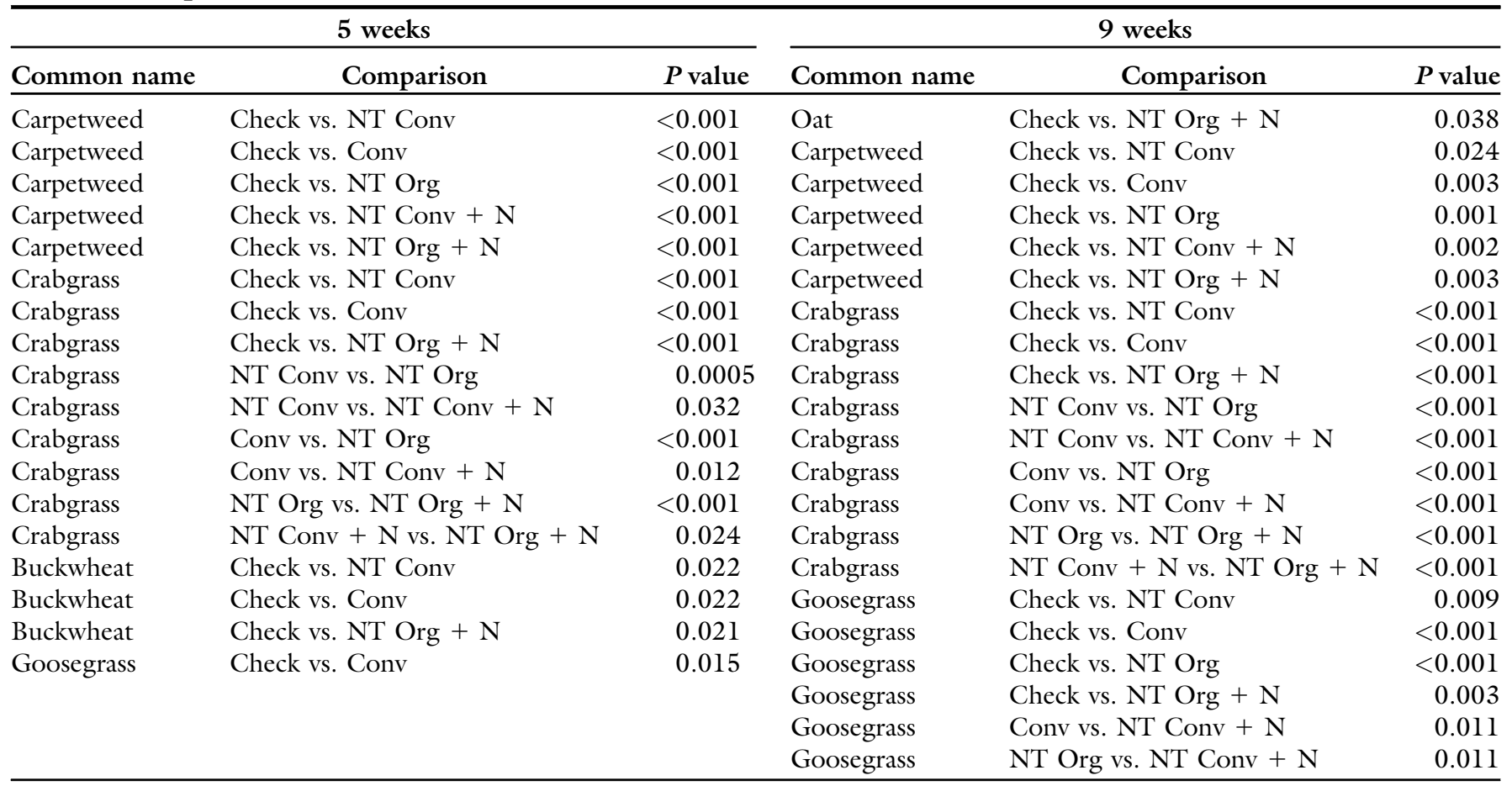

Table 5. Effect of treatments on weed species present in 'Obsession' sweet corn experimental plots at two sampling dates from year 2 (2019-20).

\begin{tabular}{lcccc}
\hline & \multicolumn{4}{c}{ Multiresponse permutation procedure } \\
\cline { 2 - 5 } Sample & $A^{\mathbf{z}}$ & Expected $\boldsymbol{\delta}^{\mathbf{y}}$ & ${\text { Observed } \boldsymbol{\delta}^{\mathbf{x}}}$ & $\boldsymbol{P}_{\text {value }}$ \\
\hline 5 weeks & 0.142 & 0.098 & 0.084 & 0.001 \\
9 weeks & 0.233 & 0.073 & 0.057 & 0.001 \\
\hline
\end{tabular}

${ }^{\mathrm{z}}$ Chance-corrected within-group agreement.

${ }^{y}$ Expected weighted mean within-group distance.

${ }^{\mathrm{x}}$ Observed weighted mean within-group distance.

Table 6. Pairwise comparisons testing the effect of treatment on weed abundance within 'Obsession' sweet corn plots at Watkinsville, GA from year 2 (2019-20) at 5 and 9 weeks with corrections for multiple testing. See Table 1 for detailed treatment descriptions.

\begin{tabular}{|c|c|c|c|c|c|}
\hline \multirow[b]{2}{*}{ Treatment $^{\mathrm{z}}$} & \multicolumn{5}{|c|}{5 weeks } \\
\hline & Check & NT Conv & Conv & NT Org & $\mathrm{NT}$ Org $+\mathrm{N}$ \\
\hline NT Conv & $0.003^{\mathrm{z}}$ & - & - & - & - \\
\hline Conv & 0.003 & 0.305 & - & - & - \\
\hline NT Org & 0.003 & 0.045 & 0.032 & - & - \\
\hline $\mathrm{NT}$ Org $+\mathrm{N}$ & 0.003 & 0.726 & 0.724 & 0.367 & - \\
\hline \multirow[t]{3}{*}{$\mathrm{NT}$ Conv $+\mathrm{N}$} & 0.003 & 0.758 & 0.345 & 0.052 & 0.758 \\
\hline & \multicolumn{5}{|c|}{9 weeks } \\
\hline & Check & NT Conv & Conv & NT Org & $\mathrm{NT}$ Org $+\mathrm{N}$ \\
\hline NT Conv & 0.0017 & - & - & - & - \\
\hline Conv & 0.0017 & 1 & - & - & - \\
\hline NT Org & 0.009 & 0.0017 & 0.0017 & - & - \\
\hline $\mathrm{NT}$ Org $+\mathrm{N}$ & 0.0505 & 0.0017 & 0.0017 & 0.3113 & - \\
\hline $\mathrm{NT}$ Conv $+\mathrm{N}$ & 0.0017 & 1 & 1 & 0.0017 & 0.0017 \\
\hline
\end{tabular}

${ }^{\mathrm{z}}$ Significance at the 0.05 level.
Grass species related to the no-till treatments are generally wind dispersed, contributing to their establishment in the absence of tillage. Increased grass emergence can also be due to seedling emergence because many grasses are able to germinate and establish on a firm soil surface covered with residue that maintains soil moisture (Tuesca et al., 2001). These results indicate that different cropping systems have significant impacts on weed assemblages, and species shifts can occur in only one season.

The data from this study suggest that cover crops and no-till, when used in combination with conventional practices, can provide comparable weed control to conventionally grown sweet corn without significant yield losses. When used with organic herbicides, cover crops and no-till did not offer the same level of weed suppression throughout the season. For use within organic production, these practices may be applicable if a grower provides additional weed control. However, weed control that does not include mechanical methods (soil disturbance) is time-consuming and may only be appropriate on a small scale. The increased nitrogen applied also did not increase yields consistently. 
Table 7. Effect of treatment on weed species present in 'Obsession' sweet corn plots at Watkinsville, GA, from year 2 (2019-20) as determined by indicator species analysis. See Table 1 for treatment description and Supplemental Table 1 for further weed species information.

\begin{tabular}{llrrrr}
\hline Species & \multicolumn{1}{c}{ Association } & $A^{\mathbf{z}}$ & $B^{\mathbf{y}}$ & IV $^{\mathbf{x}}$ & $P$ value \\
\hline & & $\mathbf{5}$ weeks & & & \\
Carpetweed & Check & 0.802 & 0.875 & 0.838 & 0.001 \\
Buckwheat & Check & 0.667 & 0.208 & 0.373 & 0.013 \\
Goosegrass & Check, NT Org & 0.712 & 0.313 & 0.472 & 0.009 \\
Crabgrass & Check, NT Org, NT Org + N & 0.9015 & 0.625 & 0.751 & 0.001 \\
& & $\mathbf{9}$ weeks & & & \\
Carpetweed & Check & 0.528 & 0.625 & 0.575 & 0.003 \\
Goosegrass & Check, NT Org + N & 0.892 & 0.417 & 0.610 & 0.001 \\
Amaranthus & Check, NT Org + N & 0.941 & 0.167 & 0.396 & 0.012 \\
Oat & NT Conv, NT Conv + N & 0.667 & 0.345 & 0.486 & 0.012 \\
Crabgrass & Check, NT Org, NT Org + N & 0.935 & 0.931 & 0.933 & 0.001 \\
\hline
\end{tabular}

${ }^{\mathrm{z}}$ Specificity: sample estimate of the probability that the surveyed site belongs to the target site group given the fact that the species has been found.

y Sensitivity: sample estimate of the probability of finding the species in sites belonging to the site group.

${ }^{x}$ Indicator index value as determined by indicator species analysis. Measures the association between a species and the site group (treatment).

The multivariate analyses identified species that were significantly associated with NT Org and NT Conv treatments. Understanding the weed communities present in agricultural systems is directly related to management decisions. The results support previous findings (Barroso et al., 2015; Kruidhof et al., 2008; Smith, 2006; Thomas et al., 2004) that different management decisions apply selection pressure to weeds and alter the community's structure over time. Manipulating other practices such as tillage type and timing, fertilizer, and herbicide application will further affect how weed communities assemble. Knowing how these practices may influence weed populations allows for more finely tuned weed management choices to target problematic species.

Crop YIELD. Specific measurements of crop performance and yield were significantly affected by the treatments (Table 8). Plant height was affected in the first year. Plants from the Check, NT Org, and NT Org + $\mathrm{N}$ treatments were shorter than the Conv, NT Conv, and NT Conv $+\mathrm{N}$ treatments. Plants shorter in height can be shaded out by surrounding plants, reducing their exposure to photosynthetically active radiation. Photosynthetic $\mathrm{CO}_{2}$ exchange rates decline with shading (Ephrath et al., 1993), reducing yield potential. Ear length was significantly affected by treatments only in year 1 . In year 2 , the measured ear length within each treatment was consistent with the average variety length of 8 inches. Tip fill was measured but not included in the analysis because $\approx 90 \%$ or more of harvested corn had some level of tip damage due to corn earworm (Helicoverpa zea).

In year 1 , the NT Conv and Conv treatments had the highest yield, 6844 and $7721 \mathrm{lb} /$ acre, respectively (Table 8). Yields from these two treatments were not different from one another $(P=0.592)$. The additional nitrogen did not significantly affect the NT Org, and NT Org + N. However, the NT Conv + N's yield was significantly lower than the NT Conv $(P=0.035)$. Past studies have found that weed species are as responsive to higher $\mathrm{N}$ levels as the crop. The results here follow previous findings that increased fertilizer may benefit weeds at the crop's expense (Blackshaw et al., 2003, 2004; Di Tomaso, 1995), leading to reduced yield. The total yield of the treatments varied between the first and second years of study. This variation could be due to the delayed planting date in year 2. Later planting dates have been shown to have decreased weed pres-

Table 8. The effect of treatments on 'Obsession' sweet corn yield, individual ear weight, ear length, and plant height for experimental year 1 (2018-19) and year 2 (2019-20) at Watkinsville, GA. Probabilities reported from preplanned comparisons of interest. See Table 1 for abbreviations and detailed treatment description.

\begin{tabular}{|c|c|c|c|c|c|c|c|c|}
\hline \multirow[b]{2}{*}{ Treatment } & \multicolumn{2}{|c|}{$\begin{array}{l}\text { Total yield } \\
(\mathrm{lb} / \mathrm{acre})^{\mathrm{z}}\end{array}$} & \multicolumn{2}{|c|}{$\begin{array}{c}\text { Ear wt } \\
(\mathrm{lb})^{\mathrm{z}}\end{array}$} & \multicolumn{2}{|c|}{$\begin{array}{l}\text { Ear length } \\
\text { (inches) }^{z}\end{array}$} & \multicolumn{2}{|c|}{$\begin{array}{l}\text { Plant ht } \\
\text { (inches) }\end{array}$} \\
\hline & Year 1 & Year 2 & Year 1 & Year 2 & Year 1 & Year 2 & Year 1 & Year 2 \\
\hline NT Conv & 6844 & 3728 & 0.560 & 0.658 & 7.86 & 8.07 & 59.7 & 67.2 \\
\hline Conventional & 7721 & 5947 & 0.505 & 0.733 & 7.87 & 7.98 & 61.7 & 65.5 \\
\hline NT Org & 1628 & 2118 & 0.338 & 0.642 & 6.55 & 7.54 & 44.2 & 63.3 \\
\hline $\mathrm{NT}$ Conv $+\mathrm{N}$ & \multicolumn{8}{|c|}{ Preplanned comparison probabilities ${ }^{\mathrm{y}}$} \\
\hline Overall & 0.002 & 0.000 & 0.013 & 0.05 & 0.004 & NS & 0.002 & NS \\
\hline Check vs. Other & 0.020 & 0.363 & 0.059 & 0.714 & 0.004 & & 0.009 & \\
\hline Conv vs. NT Conv & 0.592 & 0.003 & 0.514 & 0.025 & 1.0 & & 0.692 & \\
\hline NT Org vs. NT Org + N & 0.439 & 0.147 & 0.999 & 0.018 & 0.736 & & 0.631 & \\
\hline
\end{tabular}

${ }^{\mathrm{z}} 1 \mathrm{lb} / \mathrm{acre}=1.1209 \mathrm{~kg} \cdot \mathrm{ha}^{-1}, \mathrm{l} \mathrm{lb}=0.4536 \mathrm{~kg}, \mathrm{l}$ inch $=2.54 \mathrm{~cm}$.

${ }^{\mathrm{y}}$ Probabilities significant at 0.05 level; $\mathrm{Ns}=$ not significant. 
sure compared with earlier planting dates in both sweet corn and soybean production (Buhler and Gunsolus, 1996; Williams, 2009). Lower weed pressure means less competition for resources, thus increasing the crop's nitrogen, contributing to the increased yield.

Individual ear weight was determined by dividing the total weight from the treatment plot by the total number of ears harvested. The weight of individual ears was significantly different between treatments in both years $(P=0.013, P=$ $0.05)$. These results followed a similar pattern as the overall yield. In year 1 , ears from NT Org, NT Conv + N, and NT Org $+\mathrm{N}$ had the lowest individual weight but were significantly higher than the check. Ears from the NT Conv treatment weighed significantly more than those from the NT Conv $+\mathrm{N}$ treatment $(P=0.005)$. This result corresponds to the difference between the two treatments in the overall yield as well.

A key difference in yield and ear weight between years 1 and 2 of the study was the check treatment. In year 1 , the check had the lowest overall yield and individual ear weight. In year 2, the yield and ear weight of the check was not significantly lower than any other treatment $(P=0.363)$. These differences could be due to the later planting date in year 2 and weather variations because year 2 had greater rainfall during the experiment. In year 1 , the NT Conv yield was not significantly different from the Conv yield, but yields in year 2 were significantly lower in the NT Conv $(P=0.003)$. The variation in the yield of the no-till treatments is consistent with past studies that reported unreliable crop yields under reduced tillage (Delate et al., 2012; Díaz-Pérez et al., 2008; Herrero et al., 2001; Weil and Lounsbury, 2015). Inconsistent yields can be a deterrent for growers to convert to a reduced tillage system. Still, the results suggest that no-tillage can produce comparable sweet corn yields to tilled systems when combined with an oat cover crop. Future studies focusing on maintaining yield stability under cover crops and reduced tillage are needed to optimize these practices within various crop systems, including vegetables.

\section{Literature cited}

Bàrberi, P. 2002. Weed management in organic agriculture: Are we addressing the right issues? Weed Res. 42:177-193, https://doi.org/10.1046/j.1365-3180. 2002.00277.x.

Barroso, J., Z. Miller, E. Lehnhoff, P. Hatfield, and F. Menalled. 2015. Impacts of cropping system and management practices on the assembly of weed communities. Weed Res. 55:426-435, https:// doi.org/10.1111/wre.12155.

Blackshaw, R.E., R.N. Brandt, H.H. Janzen, T. Entz, C.A. Grant, and D.A. Derksen. 2003. Differential response of weed species to added nitrogen. Weed Sci. 51:532-539, https://doi.org/10.1614/0043-1745 (2003)051[0532:DROWST]2.0.CO;2.

Blackshaw, R.E., L.J. Molnar, and H.H. Janzen. 2004. Nitrogen fertilizer timing and application method affect weed growth and competition with spring wheat. Weed Sci. 52:614-622, https://doi.org/10.1614/ WS-03-104R.

Booth, B.D. and C.J. Swanton. 2002. Assembly theory applied to weed communities. Weed Sci. 50:2-13, https://doi. org/10.1614/0043-1745(2002)050[0002: AIATAT]2.0.CO;2.

Booth, B.D. S.D. Murphy and C.J. Swanton. 2010. Invasive plant ecology in natural and agricultural systems. 2nd ed. CAB International, Cambridge, MA.

Buhler, D.D., E.S. David, R.L. Becker, and L.G. Jeffery. 1994. Perennial weed populations after 14 years of variable tillage and cropping practices. Weed Sci. 42:205-209.

Buhler, D.D. and J.L. Gunsolus. 1996. Effect of date of preplant tillage and planting on weed populations and mechanical weed control in soybean (Glycine max). Weed Sci. 44:373-379.

Busari, M.A., S.S. Kukal, A. Kaur, R. Bhatt, and A.A. Dulazi. 2015. Conservation tillage impacts on soil, crop and the environment. Int. Soil Water Conserv. Res. 3:119-129, https://doi.org/10.1016/j.iswcr.2015.05. 002.

Cáceres, M.D. and P. Legendre. 2009. Associations between species and groups of sites: Indices and statistical inference. Ecology 90:3566-3574, https://doi.org/ 10.1890/08-1823.1.

Clark, A. (ed.). 2008. Managing cover crops profitably. Diane Publ., College Park, MD.

Clarke, K.R. 1993. Non-parametric multivariate analyses of changes in community structure. Austral. J. Ecol. 18:117-143, https://doi.org/10.1111/j.14429993. 1993.tb00438.x.

Creamer, N.G., M.A. Bennett, B.R. Stinner, J. Cardina, and E.E. Regnier. 1996. Mechanisms of weed suppression in cover crop- based production systems. HortScience 31:410-413, https://doi.org/10.21273/ HORTSCI.31.3.410.

Culpepper, A.S. 2015. Commercial vegetables weed control, p. 776-779. In: Georgia pest control handbook-Commercial edition. Coop. Ext. Serv., Univ. Georgia, College Agr. Environ. Sci., Athens.

Delate, K., D. Cwach, and C. Chase. 2012. Organic no-tillage system effects on soybean, corn and irrigated tomato production and economic performance in Iowa, USA. Renew. Agr. Food Syst. 27:49-59, https://doi.org/10.1017/S1742170511 000524.

Di Tomaso, J.M. 1995. Approaches for improving crop competitiveness through the manipulation of fertilization strategies. Weed Sci. 43:491-497.

Diamond, J.M. 1975. Assembly of species communities, p. 342-444. In: M.L. Cody, R.H. MacArthur, and J.M. Diamond (eds.). Ecology and evolution of communities. Harvard Univ. Press, Cambridge, MA.

Díaz-Pérez, J., J. Silvoy, S. Phatak, J. Ruberson, and R. Morse. 2008. Effect of winter cover crops and no-till on the yield of organically-grown bell pepper (Capsicum annum L.). Acta Hort. 767:243-247, https://doi.org/10.17660/ActaHortic. 2008.767.25.

Doran, J.W. and M.S. Smith. 1991. Role of cover crops in nitrogen cycling, $\mathrm{p}$. 85-90. In: W.L. Hargrove (ed.). Cover crops for clean water. Soil Water Conservation Soc., Ankeny, IA.

Dufrêne, M. and P. Legendre. 1997. Species assemblages and indicator species: The need for a flexible asymmetrical approach. Ecol. Monogr. 67:345-366, https:// doi.org/10.1890/0012-9615(1997)067 [0345:SAAIST]2.0.CO;2.

Dyck, E. and M. Liebman. 1995. Cropweed interference as influenced by a leguminous or synthetic fertilizer nitrogen source: II. Rotation experiments with crimson clover, field corn, and lambsquarters. Agr. Ecosystems Environ. 56:109-120, https://doi.org/10.1016/0167-8809(95) 00644-3.

Ephrath, J.E., R.F. Wang, K. Terashima, J.D. Hesketh, M.G. Huck, and J.W. Hummel. 1993. Shading effects on soybean and corn. Biotronics 22:15-24.

Fennimore, S.A. and D.J. Doohan. 2008. The challenges of specialty crop weed control, future directions. Weed Technol. 22:364-372, https://doi.org/10.1614/ WT-07-102.1.

Florence, A.M., L.G. Higley, R.A. Drijber, C.A. Francis, and J.L. Lindquist. 2019. Cover crop mixture diversity, biomass 
productivity, weed suppression, and stability. PLoS One 14:e0206195, https://doi. org/10.1371/journal.pone.0206195.

Freeman, M.F. and J.W. Tukey. 1950. Transformations related to the angular and the square root. Ann. Math. Stat. 21: 607-611, https://doi.org/10.1214/aoms/ 1177729756.

Gaskin, J.W., D. Hancock, U. Saha, and K. Chatam. 2015. Cover crop biomass sampling. Univ. of Georgia Ext. Circ. 1077.

Gower, J.C. 1971. A general coefficient of similarity and some of its properties. Biometrics 27:857-871, https://doi.org/ $10.2307 / 2528823$.

Grandy, A.S., T.D. Loecke, S. Parr, and G.P. Robertson. 2006. Long-term trends in nitrous oxide emissions, soil nitrogen, and crop yields of till and no-till cropping systems. J. Environ. Qual. 35:1487-1495, https://doi.org/10.2134/jeq2005.0166.

Haramoto, E.R. and E.R. Gallandt. 2005. Brassica cover cropping: I. Effects on weed and crop establishment. Weed Sci. 5:695-701, https://doi.org/10.1614/ WS-04-162R.1.

Hartwig, N.L. and H.U. Ammon. 2002. Cover crops and living mulches. Weed Sci. 50:688-699, https://doi.org/10.1614/ 0043-1745(2002)050[0688:AIACCA]2.0. $\mathrm{CO} ; 2$.

Herrero, E.V., J.P. Mitchell, W.T. Lanini, S.R. Temple, E.M. Miyao, R.D. Morse, and E. Campiglia. 2001. Use of cover crop mulches in a no-till furrow-irrigated processing tomato production system. HortTechnology 11:43-48, https://doi.org/ 10.21273/HORTTECH.11.1.43.

Hill, E. and C. Sprague. 2021. Cover crop termination. 21 Apr. 2021. < https://www. canr.msu.edu/cover_crops/uploads/files / CLS\%20Termination2021.pdf>.

Karlen, D.L., N.C. Wollenhaupt, D.C. Erbach, E.C. Berry, J.B. Swan, N.S. Eash, and J.L. Jordahl. 1994. Long-term tillage effects on soil quality. Soil Tillage Res. 32:313-327, https://doi.org/10.1016/ 0167-1987(94)00427-G.

Kruidhof, H.M., L. Bastiaans, and M.J. Kropff. 2008. Ecological weed management by cover cropping: Effects on weed growth in autumn and weed establishment in spring. Weed Res. 48:492-502, https://doi.org/ 10.1111/j.1365-3180.2008.00665.x.

Legleiter, T., B. Johnson, T. Jordan, and K. Gibson. 2012. Successful cover crop termination with herbicides. Purdue Univ., Purdue Ext. Bul. WS-50-W.

MacLaren, C., P. Swanepoel, J. Bennett, J. Wright, and K. Dehnen-Schmutz. 2019. Cover crop biomass production is more important than diversity for weed suppres- sion. Crop Sci. 59:733-748, https:// doi.org/10.2135/cropsci2018.05.0329.

McCune, B., J.B. Grace, and D.L. Urban. 2002. Analysis of ecological communities. J. Exp. Mar. Biol. Ecol. 289:303-305, https://doi.org/10.1016/S0022-0981(03) 00091-1.

Mulvaney, M.J., A.J. Price, and C.W. Wood. 2011. Cover crop residue and organic mulches provide weed control during limited-input no-till collard production. J. Sustain. Agr. 35:312-328, https://doi.org/ 10.1080/10440046.2011.554315.

Ngouajio, M., M. McGiffen, Jr., and C. Hutchinson. 2003. Effect of cover crop and management system on weed populations in lettuce. Crop Prot. 22:57-64, https://doi. org/10.1016/S0261-2194(02)00111-4.

Nielsen, R.L. 2003. Tip fill problems in corn. Purdue Univ. Dept. Agr. Corny News Network, West Lafayette, IN.

Nkoa, R., M.D.K. Owen, and C.J. Swanton. 2015. Weed abundance, distribution, diversity, and community analyses. Weed Sci. 63:64-90, https://doi.org/10.1614/ WS-D-13-00075.1.

Oksanen, J., F.G. Blanchet, M. Friendly, R. Kindt, P. Legendre, D. McGlinn, P.R. Minchin, R.B. O'Hara, G.L. Simpson, P. Solymos, M.H.H. Stevens, E. Szoecs, and H. Wagner. 2020. vegan: Community Ecology Package. R package version 2.5-7. 1 May 2021. <https://CRAN.R-project. org $/$ package $=$ vegan $>$.

Oktem, A., A.G. Oktem, and H.Y. Emeklier. 2010. Effect of nitrogen on yield and some quality parameters of sweet corn. Commun. Soil Sci. Plant Anal. 41:832-847, https:// doi.org/10.1080/00103621003592358.

Osipitan, O.A., J.A. Dille, Y. Assefa, and S.Z. Knezevic. 2018. Cover crop for early season weed suppression in crops: Systematic review and meta-analysis. Agron. J. 110: 2211-2221, https://doi.org/10.2134/ agronj2017.12.0752.

Pollnac, F.W., B.D. Maxwell, and F.D. Menalled. 2009. Using species-area curves to examine weed communities in organic and conventional spring wheat systems. Weed Sci. 57:241-247, https://doi.org/ 10.1614/WS-08-159.1.

Riley, H., R. Pommeresche, R. Eltun, S. Hansen, and A. Korsaeth. 2008. Soil structure, organic matter and earthworm activity in a comparison of cropping systems with contrasting tillage, rotations, fertilizer levels and manure use. Agr. Ecosystems Environ. 124:275-284, https:// doi.org/10.1016/j.agee.2007.11.002.

Smith, R.G. 2006. Timing of tillage is an important filter on the assembly of weed com- munities. Weed Sci. 54:705-712, https:// doi.org/10.1614/WS-05-177Rl.1.

Soltani, N., J.A. Dille, I.C. Burke, W.J. Everman, M.J. VanGessel, V.M. Davis, and P.H. Sikkema. 2016. Potential corn yield losses from weeds in North America. Weed Technol. 30:979-984, https:// doi.org/10.1614/WT-D-16-00046.1.

Sp, P. 2012. Response of sweet corn hybrid to varying plant densities and nitrogen levels. Afr. J. Agr. Res. 7:6158-6166, https://doi.org/10.5897/AJAR12.557.

Teasdale, J.R. and C.L. Mohler. 1993. Light transmittance, soil temperature, and soil moisture under residue of hairy vetch and rye. Agron. J. 85:673-680, https:// doi.org/10.2134/agronj1993.00021962 008500030029x.

Thomas, A.G., D.A. Derkson, R.E. Blackshaw, R. Van Acker, A. Légère, P.R. Watson, and G.C. Turnbull. 2004. A multistudy approach to understanding weed population shifts in medium- to long-term tillage systems. Weed Sci. 52:874-880, https:// doi.org/10.1614/WS-04-010Rl.

Tuesca, D., E. Puricelli, and J.C. Papa. 2001. A long-term study of weed flora shifts in different tillage systems. Weed Res. 41:369-382, https://doi.org/10.1046/ j.13653180.2001.00245.x.

University of Georgia. 2020. WatkinsvilleHorticulture, Georgia climate data. 1 Sept. 2020. <http://www.georgiaweather.net/ ? content $=$ calculator $\&$ variable $=$ CC\&site $=$ WATHORT $>$.

U.S. Department of Agriculture. 2017. National organic program organic regulations, 82 Fed. Reg. 14420-14425. U.S. Dept. Agr., Washington, DC.

eil, R. and N. Lounsbury. 2015. No-till seeded spinach after winterkilled cover crops in an organic production system. Renew. Agr. Food Syst. 30:473-485, https:// doi.org/10.1017/S1742170514000301.

Williams, M. 2009. Planting date influences critical period of weed control in sweet corn. Weed Sci. 54:928-933, https:// doi.org/10.1614/WS-06-005R.1.

Wortman, S.E., C.A. Francis, M.A. Bernards, E.E. Blankenship, and J.L. Lindquist. 2013. Mechanical termination of diverse cover crop mixtures for improved weed suppression in organic cropping systems. Weed Sci. 61:162-170, https:// doi.org/10.1614/WS-D-12-00066.1.

Zimmerman, G.M., H. Goetz, and P.W. Mielke. 1985. Use of an improved statistical method for group comparisons to study effects of prairie fire. Ecology 66:606-611, https://doi.org/10.2307/ 1940409. 
Supplemental Table 1. Weed species present within 'Obsession' sweet corn plots at Watkinsville, GA, during experimental year 1 (2018-19) and year $2(2019-20)$.

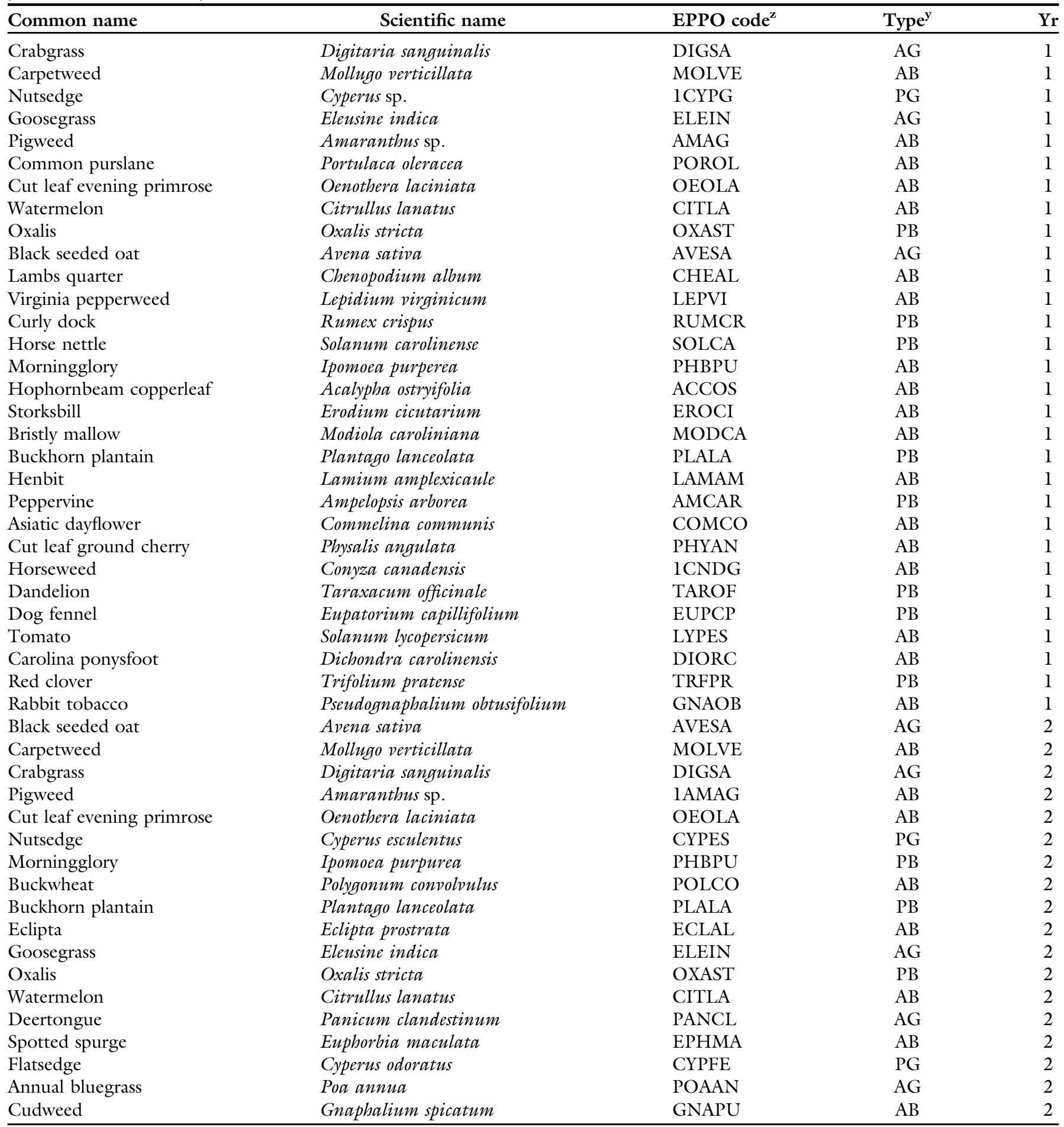

${ }^{\mathrm{z}}$ European and Mediterranean Plant Protection Organization code.

${ }^{\mathrm{y}} \mathrm{AG}=$ annual grass; $\mathrm{AB}=$ annual broadleaf; $\mathrm{PG}=$ perennial grass; $\mathrm{PB}=$ perennial broadleaf. 